\title{
Is the Seed Dispersal Related to Spatial Pattern of Individuals in Populations? The Case of Dalbergía cearensis
}

\author{
Francisco Carlos Barboza Nogueira' ${ }^{*}$, Sebastião Medeiros Filho², \\ Raquel Negrão Baldoni' ${ }^{3}$, Talita Ariela Sampaio e Silva ${ }^{3}$ \\ ${ }^{1}$ Brazilian Institute of Environment and Renewable Natural Resources-IBAMA, Fortaleza, Brazil \\ ${ }^{2}$ Seed Analysis Laboratory, Department of Phytotecnic, Federal University of Ceará-UFC, Fortaleza, Brazil \\ ${ }^{3}$ Graduate Program in Ecology and Natural Resources, Department of Botany, Federal University of São Carlos, \\ São Paulo, Brazil \\ Email: fcbarbozanogueira@hotmail.com
}

Received 10 July 2014; revised 16 August 2014; accepted 5 September 2014

Copyright (C) 2014 by authors and Scientific Research Publishing Inc.

This work is licensed under the Creative Commons Attribution International License (CC BY). http://creativecommons.org/licenses/by/4.0/

\section{(c) (i) Open Access}

\section{Abstract}

The spatial distribution of plant species reveals how members of a population are horizontally organized in the environment. Individuals at different development stages can be influenced differently by abiotic and biotic factors because they are temporally separated. This may cause changes in spatial patterns in ontogenetic stages. The objectives of this study were to verify the pattern of spatial distribution of saplings and adults in Dalbergia cearensis Ducke and relate it to the pattern of seed dispersal. In two areas of 4.0 ha each, located in a Private Natural Heritage Reserve (RPPN) "Não Me Deixes", there were counted all saplings and adults. This data were applied to the spatial analysis by distance indices, using the software Sadie Shell, version 8.0. The aggregation index (Ia) of adults was significant for both areas and showed aggregated distribution. $D$. cearensis saplings showed an aggregated distribution in the area I and area II. The dispersion distance was proportional for both areas, and the highest proportion of seeds was $10-20 \mathrm{~m}$ away from the center of the aggregation. Spatial analysis by distance indices showed an aggregated spatial distribution pattern for saplings and adults of $D$. cearensis.

\section{Keywords}

Clusters, Patches, Spatial Pattern, Aggregation, SADIE System

\footnotetext{
*Corresponding author.
}

How to cite this paper: Nogueira, F.C.B., Filho, S.M., Baldoni, R.N. and Sampaio, T.A.S. (2014) Is the Seed Dispersal Related to Spatial Pattern of Individuals in Populations? The Case of Dalbergia cearensis. American Journal of Plant Sciences, 5, 2997-3004. http://dx.doi.org/10.4236/ajps.2014.520316 


\section{Introduction}

Patterns in distribution of plants reveal how members of a population are arranged horizontally in the environment and may reflect past conditions [1]. The dispersal pattern of a plant population depends on the interaction of two factors, seed dispersal and probability of survival of their seedlings [2]. The amount of seeds dispersed over long distances can reduce the likelihood of them reaching suitable habitat and there is no sapling recruitment [3].

The spatial pattern of adult plants depends on the recruitment spatial pattern because mortality is density dependent [4]. Moreover, the survival of seedling in the soil is influenced by the distance from parental plant. According to Janzen [5] and Connell [6], seedling mortality is higher near the parent plant due to pressure from predators and pathogens. Thus, the recruitment should occur at intermediate distance from the parent plant. On the other hand, Hubbell [7] revised this model and suggested that the maximum number of offspring recruited should be near the parental, unless $100 \%$ of deaths occur near it. This occurs because of the higher density of seeds near to the parental plant. Therefore, even if mortality is higher near the parental plant, the absolute number of survivors is greater.

The spatial distribution of plant species may prove an indispensable tool of analysis to infer ecological processes involved in population dynamics. The spatial pattern of trees can be used to analyze the ecological characteristics of species such as tolerance to germinate in shade or light [8], negative interactions such as competition [9], dispersion [2], seedling recruitment [10] or adult-juvenile relationship [11].

In an environment marked by climatic seasonality, processes like seed dispersal, seed banks in soil and seedling establishment are separated in time [12]. This fact makes the opportunity for the abiotic and biotic factors determine the spatial distribution pattern of the adults. Spatial heterogeneity plays an important role in semiarid regions, through its influence on processes of seed germination and seedling establishment. In these regions, the spatial pattern of seedling survival becomes strongly aggregated with well defined spots (areas of high survival) and gaps that represent areas of low survival [13]. In general, the semiarid regions show a remarkable diversity of spatial patterns according to species and size classes. However, the aggregate pattern dominates most monospecific distributions [14].

The semiarid vegetation (Caatinga) shows climatic seasonality [15]. Dalbergia cearensis Ducke, Fabaceae is an endemic species in the semiarid region of northeastern Brazil [16]. Assuming that their seeds do not form a persistent bank in the soil, the seeds produced in a given year are responsible for seedling recruitment in the subsequent rainy season. Indeed, the opportunity for recruitment is influenced by a number of ecological factors [2] [5]-[7]. These factors may cause changes in the spatial pattern of seedling establishment and affect the distribution of adults [17].

Based on this information, seed rain is so high next to the aggregation centre of mother plant in D. cearensis and there are no seeds dispersed over long distances. Consequently, our hypothesis is that the spatial distribution does not change through the stages of his life (seedling-adult). Our expectation is to find a pattern of aggregated spatial distribution of seedlings and adults of $D$. cearensis.

The main objectives of this study were to: 1) know the spatial distribution pattern of saplings and adults of $D$. cearensis and 2) and relate the use of space by this species with its ability to disperse.

\section{Materials and Methods}

\subsection{Study Site}

The study site is included in the conservation unit of sustainable use- “Não Me Deixes” Farm, in the municipality of Quixadá, Ceará (449'34"S, 3858'9"W and 210 m above sea level), Figure 1. The climate of Quixadá is classified as Aw [18], i.e., tropical wet climate with an average temperature of the coldest month greater than or equal to $18^{\circ} \mathrm{C}$ and precipitation of driest month less than $30 \mathrm{~mm}$. The climatological data of the area for the period 1980 to 2003 point to the existence of two distinct periods throughout the year [19]. A wet period (from January to May), marked by over $75 \mathrm{~mm}$ rainfall, concentrating $85.42 \%$ annual rainfall; and a dry period (from June to December), with rainfall less than $50.8 \mathrm{~mm}$, representing $14.58 \%$ annual rainfall. The average annual temperature is close to $27.2^{\circ} \mathrm{C}$, with maximum temperatures of $32.4^{\circ} \mathrm{C}$ and the mean minimum of $22.3^{\circ} \mathrm{C}$.

\subsection{Study Species and Data Collection}

Dalbergia cearensis is a tree that can reach up to 2.50 - 9 meters in the study area and its fruits develop in the 


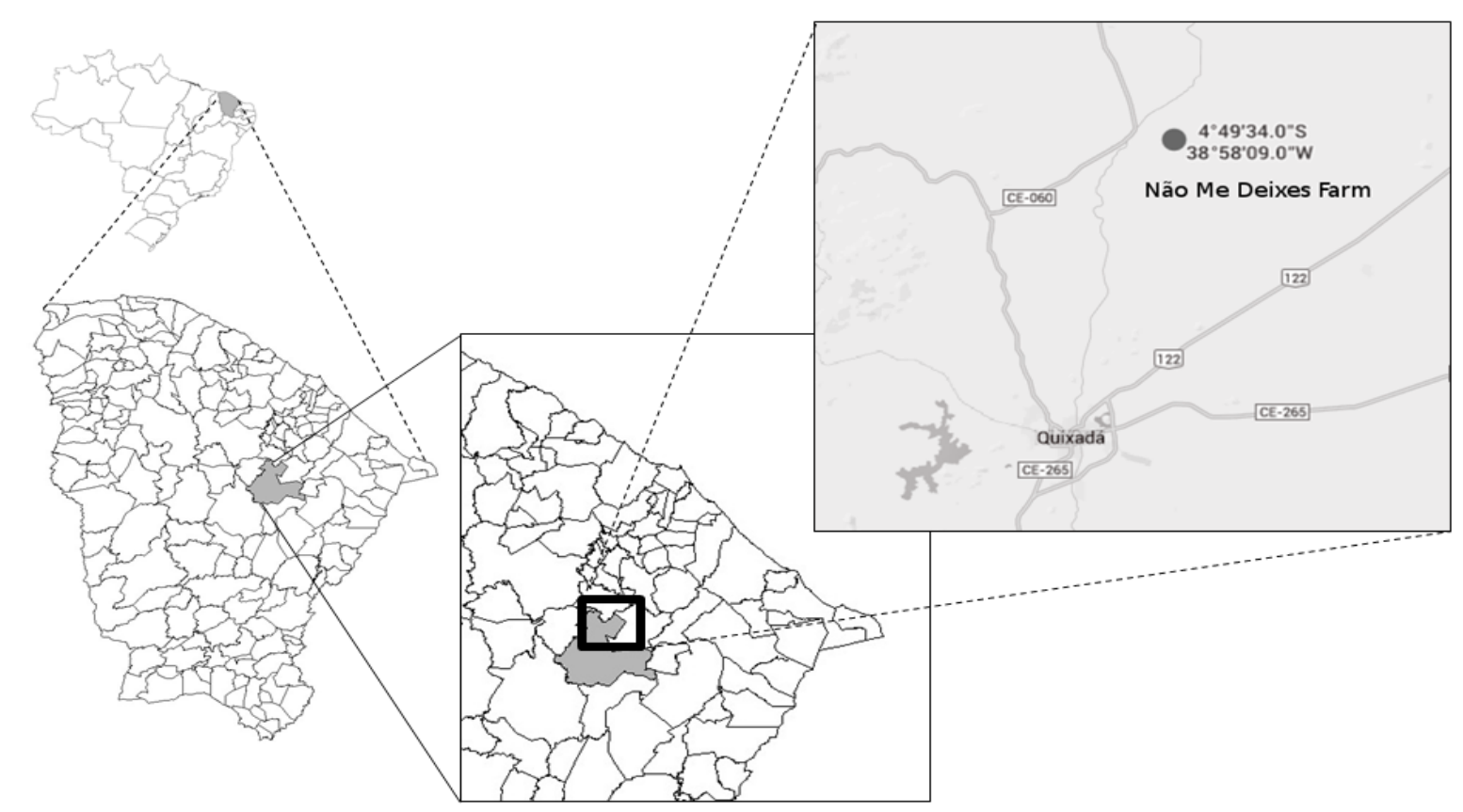

Figure 1. Location of conservation unit of sustainable use-“Não Me Deixes” Farm (4²49'34"S, 3858'9"W).

rainy season and are dispersed in the dry season (personal observation). Its seeds have no dormancy and germination begin after the third day after sowing, have a high germination percentage (70\%) [20]. In August 2011, we allocated two areas (I, II) of $200 \times 200 \mathrm{~m}$ each, divided into $20 \times 20 \mathrm{~m}$ subplots, visually identify areas where a larger amount of $D$. cearensis. The species has been explored much. The property has vegetation preserved for that reason there is the presence of the species. Two areas is a low number of replication. Therefore the results of this study cannot be extrapolated to the whole area of occurrence of the species in the semiarid region of Northeastern Brazil.

For spatial structure analysis, each plot received coordinate $\mathrm{x}$ and $\mathrm{y}$. In each subplot, we performed the count of all adults. All these adults were height greater than 2.50 meters (personal observation). We considered as saplings the individuals without cotyledons and height between 6 and $30 \mathrm{~cm}$. The absence of individuals in the subplots was represented by zero.

We installed 10 seed traps with an area of $0.25 \mathrm{~m}^{2}$ in each of the sampling sites, in the north-south direction in each 10 meters, in order to know the amount of dispersed propagules and distance of seed dispersal. We counted the number of seeds in the traps and measured the distance of each trap to the nearest adult.

\subsection{Data Analysis}

The spatial distribution of the saplings and adults of $D$. cearensis was examined using Spatial Analysis by Distance Indices_-SADIE [21]-[23]. The SADIE measures potential overall aggregation through (D_obs), distance to regularity, which is the minimum total distance individuals should move to achieve an equal sample number $n$ in each sub-plot. A larger D indicates a more spatially aggregated arrangement of counts. After a number of randomizations, Ea, simulated mean distance to regularity, can be calculated. The index of aggregation can now be defined as Ia = D_obs/Ea [24]. SADIE software uses an algorithm that moves individuals in such a way that they take up the allowable space in a regular way. This process is iterated until the arrangement converges, and the distance to regularity (D_obs) is the computed from a comparison of the initial and final arrangements. Random permutations of the spatial distribution of the $n$ points are subsequently used to calculate the distance to regularity based on a random distribution of the individuals (Dist_rand). An index of aggregation, Ia, is then obtained from the ratio of observed to permuted values of distance, calculated as the number of simulated distributions with distances greater than Dist_obs.

In this case, Ia values close to 1 indicates random distribution while values of Ia $>1$ show an aggregated distribution and Ia $<1$ indicates a regular distribution. The index (Vi) indicate patchy cluster and the index (Vj) in- 
dicate gappy cluster. For a more extensive discussion and explanation of the method, see Perry [21].

A non-parametric spatial analysis was conducted separately for saplings and adults in the two sampling sites. These calculations were made for each population and each stage, in all tests we used 30,000 permutations. Maps of the aggregation indexes were created with the Golden Software Surfer 8.0.

\section{Results}

A total of 74 adults were found in 34 of the 100 subplots of area I. In area II, 16 adults were found in 11 of 100 subplots. Adults were aggregated in both areas. Aggregation indexes (Ia) were significant and greater than 1 and the indexes Vi and Vj were also significant, with values greater than 1.0 for both areas (Table 1). High and negative $\mathrm{Vj}$ values indicate that there are gaps between patch clusters. High and positive values of Vi indicate the existence of patch clusters (Figure 2). The maps show the distribution of dark regions that represent gap areas and bright regions that represent the presence of patch of adults.

Of the 100 plots sampled in the area I, there were recorded 84 saplings in 22 subplots. For area II, six subplots contained 14 saplings. Saplings of $D$. cearensis showed a clumped distribution in the area I (Ia $=1.461)$. In area II the value of Ia was around to 1 (Ia $=1.096$ ), a result expected for random patterns (Table 1$)$. Whereas in the area I the $p$ value $(0.0102)$ was significant for the aggregate pattern, in area II this value $(p=0.2373)$ was not significant for the hypothesis of randomness. High and negative $\mathrm{Vj}$ values indicate that there are gaps between patches. High and positive Vi values and indicate the existence of patch cluster. Values of Vi and Vj positive and close to the unit indicate the existence of random patterns (Figure 2(a) and Figure 2(b)). The maps for the saplings show the distribution of dark areas much more pronounced than those of adults, which represent gap areas and bright areas represent the presence of clusters.

We found a greater amount of propagules of $D$. cearensis dispersed at 10 and 20 m away from the center of the aggregation of the area 1 and area 2, Figure 3.

\section{Discussion}

The results showed that $D$. cearensis is spatially aggregated. The presence of clusters of varying sizes suggests that the factors responsible for the observed pattern are acting locally. Environmental attributes such as topography and soil texture appear to exert some control environment for the species. The establishment of species by seeds may be conditioned by abiotic factors, such as water, light and nutrients availability [25]. Observations made in the field indicate that the population distribution is less homogeneous where the topography is higher, and the soil has less clay.

Living things in nature are not distributed uniformly or randomly [26]. Instead, they are grouped in patches; they form gradients or establish other kinds of spatial structures. The spatial pattern for saplings and adults appears to be consistent for these two life stages of $D$. cearensis. Although the distribution pattern was clustered for adults, it varied from clustered (area I) to random (area II) for saplings. However, this random distribution of saplings in area II may be the result of a few individuals concentrated in a few subplots while, in other plots, there is the complete absence of individuals. In addition, the densely clustered pattern for adults compared to saplings may suggest some relationship with patches of habitat. This may occur, or because adults can be found in more favorable locations, or while the saplings are widely dispersed [27].

Seed production is an event that varies between plants considerably due to the difference in fertility, loss of seeds before dispersal, the plant size and resource availability in the environment [3]. The distribution of individuals between the two study sites suggests environmental variation. The different number of fertile adults of

Table 1. Spatial structure of $D$. cearensis. Stages, sapling sites, number of individuals (N), aggregation index (Ia), index for patch cluster (Vi), and index for gap clusters $(\mathrm{Vj})$.

\begin{tabular}{cccccccccc}
\hline Stages & Sampling site & $\mathbf{N}$ & $\mathbf{I a}$ & $\mathbf{p}$ & $\mathbf{V i}$ & $\mathbf{p}$ & $\mathbf{V j}$ & $\mathbf{p}$ \\
\hline \multirow{2}{*}{ Adult } & Area I & 74 & 1.683 & 0.0003 & 1.629 & 0.0013 & -1.691 & 0.0007 \\
& Area II & 16 & 1.442 & 0.0150 & 1.442 & 0.0165 & -1.436 & 0.0160 \\
\multirow{3}{*}{ Sapling } & Area I & 84 & 1.461 & 0.0102 & 1.495 & 0.0047 & -1.464 & 0.0090 \\
& Area II & 14 & 1.096 & 0.2373 & 1.161 & 0.1532 & -1.075 & 0.2717 \\
\hline
\end{tabular}




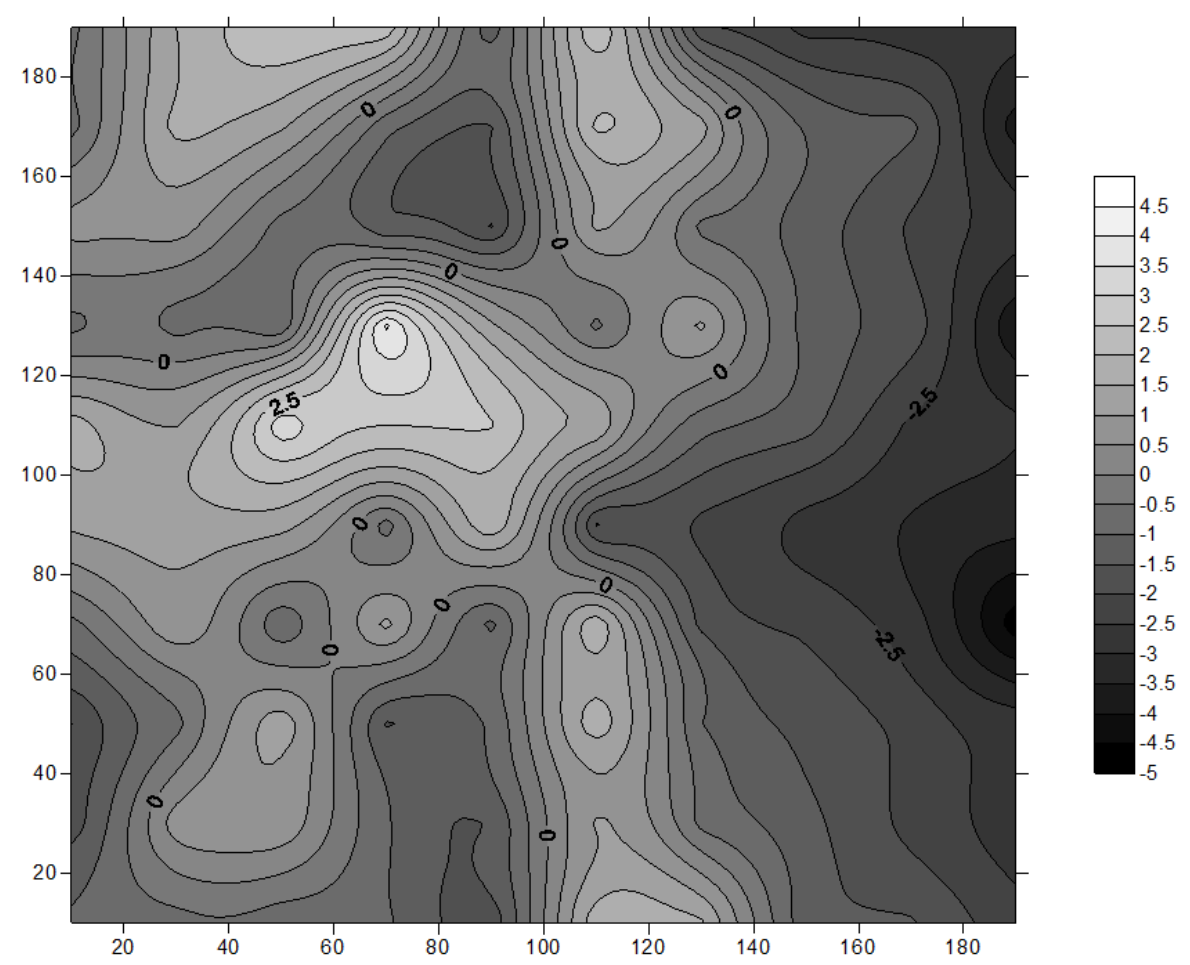

(a)

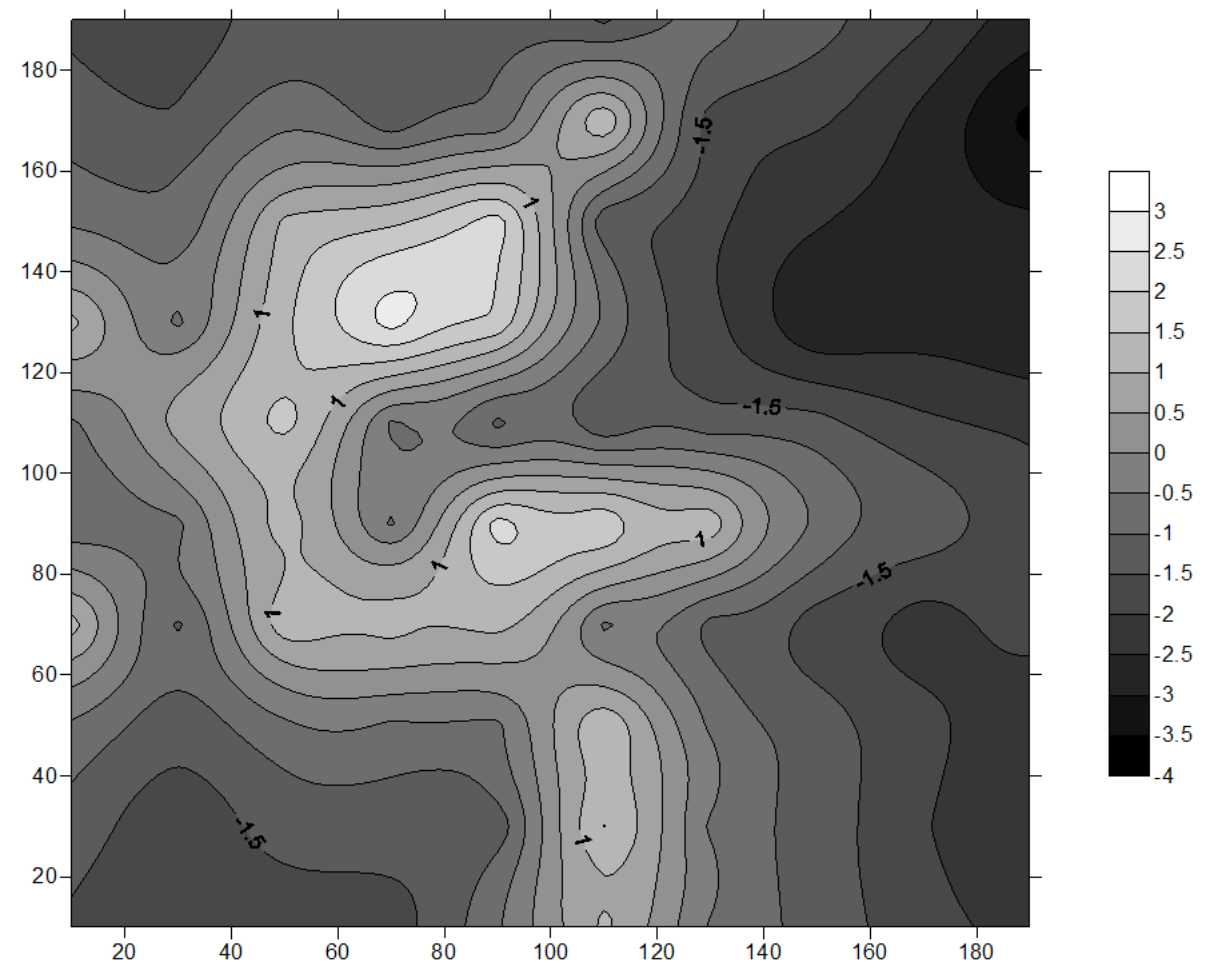

(b)

Figure 2. Map of aggregation index (V) for D. cearensis: adults (at the top) and saplings (down) in the area I. The bright regions indicate higher values of aggregation intensity (greater number of individuals more neastered). 

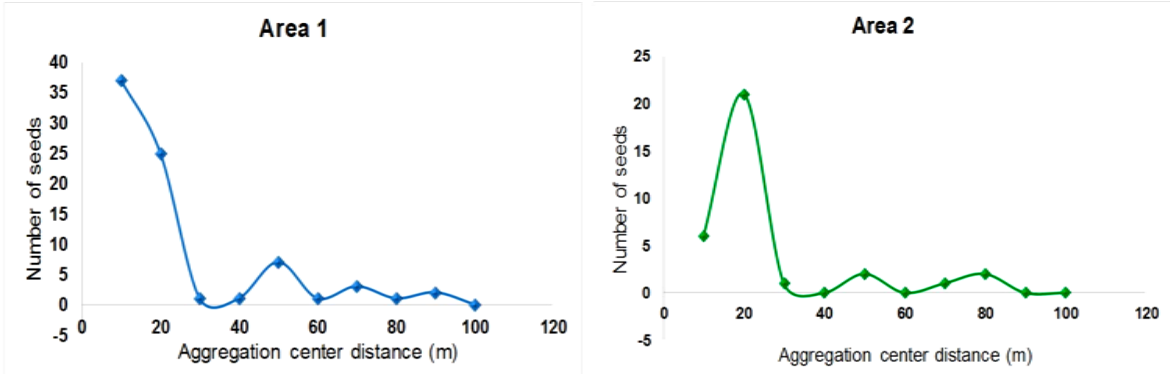

Figure 3. Quantity of $D$. cearensis seeds collected at different distances (in meters) of the aggregation centre the two studied areas.

D. cearensis in each area generated a differential production of seeds and different conditions of germination and seedling survival. However, the spread of seeds is proportionally similar in both areas. This may occur because the greatest seed abundance was found at 2 and 3 meters of distances of nearest adult, and the maximum dispersal distance was around $13 \mathrm{~m}$ (Figure 3). Okubo and Levin [28] state that the seed dispersal decreases with the increase of distance, but the peak of seeds abundance may be in a certain distance (closer) from the origin source. The same authors explain that it may occur because the dispersal distance also depends on the height of the parental tree, and on the seed deposition velocity. The absence of seeds at distances greater than $13 \mathrm{~m}$ in both areas suggests that the species has low-dispersal ability over long distances. Seed dispersal at small distances the mother plant may be reducing the likelihood of $D$. cearensis reach new safe places for the establishment of the species [29]. The pattern of seeds abundance-distribution due to an around adults, conclude that the seed dispersion for $D$. cearensis fits in the Gaussian plume models, or because the number of seeds is lower near adults, or gets higher in intermediate distances and then decreases in farthest distances [29].

For many species, flowering is spatially aggregated and then, seed dispersal and germination are often aggregated [4]. The cited author also considers that when seeds are dispersed in high density there will be a higher probability of clustered germination. Considering that 1 ) the peak of seeds abundance is in an intermediate distance from parental (our results), and 2) the success of recruitment proportionally increases with distance from adult [5] [6], we conclude that the observed pattern for seed dispersal in $D$. cearensis allows a tradeoff between the seed dispersal capacity and the possibility of recruitment success in a safe place. Moreover, it can also explain the clumped spatial pattern because higher seeds abundance is concentrated at intermediate distances. In view of Crawley [30], the aggregate distribution pattern for species that are established through the germination of seeds, stems from the density of seedlings near the parent plant and disposal of these seeds in micro-safe locations.

It is noteworthy that the scattering at intermediate distances from the parent plant can promote an aggregated distribution of seeds and keep that standard for the emerging plants. This is possible on a small scale. The aggregation of the seed in the soil creates specific associations between different seed, which is then translated into association the emerging plant level [31]. At least a small part of the spatial distribution of seedlings can be explained by the abundance of seeds. That is what gave Rusch [10] by identifying an aggregated pattern in the seed bank similar to seedling recruitment. Moreover, part of the fruits of $D$. cearensis is dispersed together with their compact axillary panicles this fact entails an increase in weight and decreases the efficiency of wind dispersal [29]. This feature for short dispersion may be responsible, at least in part, by a group of plants which are formed in the vicinity of the parent plants. However, other amounts of fruit production panicle detach slowly and gradually, are dispersed in the early season dry until the end of the rainy season follows and can reach greater distances (13 meters) dispersion [32]. In both areas, the size of adult trees of $D$. cearensis ranges from 8 to 10 meters, equaling in height the other species of the community. In the event of high wind speed, the propagules will be thrown greater distances from the local dispersion. This low stochasticity in the dispersal of propagules can be limiting for the species, whose success can be achieved through increased chances of seedlings reach a safe place to germinate and establish [25].

At a local level, the results indicate that after recruitment, the transition to young plants kept in standard household micro environments (topography, soil). This added special pattern in seedlings of $D$. cearensis was also observed in other species of semiarid regions. The survival of seedlings of Pistacia lentiscus, an evergreen 
shrub of semiarid region of southeastern Spain, showed a strongly aggregated spatial pattern over time [13]. In this case, the spatial heterogeneity played a decisive role as abiotic and not only rain water was important to vegetation dynamics in this environment. Spatial heterogeneity also revealed that environmental conditions favorable seedlings and saplings remained aggregated on a local scale [8].

The aggregated distribution pattern may indicate limited dispersal, where the density of seedlings declines sharply with the increase of distance from the parental plant [27]. Similarly, this would be expected to $D$. cearensis because it is a kind anemocoric. Their seed has dispersed within walking distance 10 - 20 meters and will loose with their difficulty in compact axillary panicles.

\section{Conclusion}

Spatial analysis by distance indices showed an aggregated spatial distribution pattern for saplings and adults of D. cearensis. The dispersion distance was proportional for both areas, and the highest proportion of seeds was 10 - $20 \mathrm{~m}$ away from the center of the aggregation.

\section{Acknowledgements}

The authors thank the owners of Private Natural Heritage Reserve-Treasury RPPN Não Me Deixes, Ms. Maria Luiza de Queiroz and her sons Flávio Salek de Queiroz and Daniel Salek Queiroz, for allowing the research unit in the conservation unity. They also thank to the Brazilian Institute of Environment and Renewable Natural Resources-IBAMA for the full-time release of the first author to pursue a Ph.D. in Ecology and Natural Resources at the Department of Biology, Federal University of Ceará.

\section{References}

[1] Kleijn, D. and Steinger, T. (2002) Contrasting Effects of Grazing and Hay Cutting on the Spatial and Genetic Population Structure of Veratrum album, an Unpalatable, Long-Lived, Clonal Plant Species. Journal of Ecology, 90, 360-370. http://dx.doi.org/10.1046/j.1365-2745.2001.00676.x

[2] Augspurger, C.K. (1983) Offspring Recruitment around Tropical Trees: Changes in Cohort Distance with Time. Oikos, 40, 189-196. http://dx.doi.org/10.2307/3544582

[3] Santos, B.A., Melo, F.P.L. and Tabarelli, M. (2006) Seed Shadow, Seedling Recruitment, and Spatial Distribution of Buchenavia capitata (Combretaceae) in a Fragment of the Brazilian Atlantic Forest. Brazilian Journal of Biology, 66, 883-890. http://dx.doi.org/10.1590/S1519-69842006000500014

[4] Hutchings, M.J. (2000) The Structure of Plant Populations. In: Crawley, M.J., Ed., Plant Ecology, Blackwell, Oxford.

[5] Janzen, D.H. (1970) Herbivores and the Number of Tree Species in Tropical Forests. American Naturalist, 104, 501528. http://dx.doi.org/10.1086/282687

[6] Connell, J.H. (1971) On the Role of Natural Enemies in Preventing Competitive Exclusion in Some Marine Animals and in Rain Forest Trees. In: Den Boer, P.J. and Gradwell, G.R., Eds., Dynamics of Populations, Centre for Agricultural Publishing and Documentation, Wageningen, The Netherlands.

[7] Hubbell, S.P. (1980) Seed Predation and the Coexistence of Tree Species in Tropical Forests. Oikos, 35, 214-229. http://dx.doi.org/10.2307/3544429

[8] Arévalo, J.R. and Fernández-Palacios, J.M. (2003) Spatial Patterns of Trees and Juveniles in a Laurel Forest of Tenerife, Canary Islands. Plant Ecology, 165, 1-10. http://dx.doi.org/10.1023/A:1021490715660

[9] Chapin, F.S., McGraw, J.B. and Shaver, G.C. (1989) Competition Causes Regular Spacing of Alder in Alaskan Shrub Tundra. Oecologia, 79, 412-416. http://dx.doi.org/10.1007/BF00384322

[10] Rusch, G. (1992) Spacial Pattern of Seedling Recruitment at Two Different Scales in a Limestone Grassland. Oikos, 65, 433-442. http://dx.doi.org/10.2307/3545560

[11] He, F., Legendre, P. and LaFrankie, J.V. (1997) Distribution Patterns of Tree Species in a Malaysian Tropical Rain Forest. Journal Vegetation Science, 8, 105-114. http://dx.doi.org/10.2307/3237248

[12] Houle, G. (1998) Seed Dispersal and Seedling Recruitment of Betula alleghaniensis: Special Inconsistency in Time. Ecology, 79, 807-818. http://dx.doi.org/10.2307/176580

[13] Maestre, F.T., Cortina, J., Bautista, S., Bellot, J. and Vallejo, R. (2003) Small-Scale Environmental Heterogeneity and Spatiotemporal Dynamics of Seedling Establishment in a Semiarid Degraded Ecosystem. Ecosystems, 6, 630-643. http://dx.doi.org/10.1007/s10021-002-0222-5

[14] Couteron, P. and Kokou, K. (1997) Woody Vegetation Spatial Patterns in a Semi-Arid Savanna of Burkina Faso, West 
Africa. Plant Ecology, 132, 211-227. http://link.springer.com/article/10.1023/A:1009723906370\#page-1 http://dx.doi.org/10.1023/A:1009723906370

[15] Andrade-Lima, D. (1981) The Caatingas Dominium. Revista Brasileira de Botânica, 4, 149-153.

[16] de Carvalho, A.M. (1997) A Synopsis of the Genus Dalbergia (Fabaceae, Dalbergieae) in Brazil. Brittonia, 49, 87-109. http://dx.doi.org/10.2307/2807701

[17] Bleher, B. and Böhning-Gaese, K. (2001) Consequences of Frugivore Diversity for Seed Dispersal, Seedling Establishment and the Spatial Pattern of Seedlings and Trees. Oecologia, 129, 385-394.

[18] Köppen, W. (1948) Climatologia: Com um estúdio de los climas de la tierra, Fondo de Cultura Economica.

[19] Empresa Brasileira de Pesquisa Agropecuária (2004) Dados climatológicos: Estação de Quixadá, 2003, Embrapa, Fortaleza.

[20] Nogueira, F.C.B., Filho, S.M. and Gallão, M.I. (2010) Caracterização da germinação e morfologia de frutos, sementes e plântulas de Dalbergia cearensis Ducke (pau-violeta)—Fabaceae. Acta Botanica Brasilica, 24, 978-985.

http://www.scielo.br/pdf/abb/v24n4/v24n4a13.pdf http://dx.doi.org/10.1590/S0102-33062010000400013

[21] Perry, J.N. (1995) Spatial Analysis by Distance Indices. Journal of Animal Ecology, 64, 303-314. http://www.jstor.org/stable/5892 http://dx.doi.org/10.2307/5892

[22] Perry, J.N. (1998) Measures of Spatial Pattern for Counts. Ecology, 79, 1008-1017. http://dx.doi.org/10.1890/0012-9658(1998)079[1008:MOSPFC]2.0.CO;2

[23] Perry, J.N., Winder, L., Holland, J.M. and Alston, R.D. (1999) Red-Blue Plots for Detecting Clusters in Count Data. Ecology Letters, 2, 106-113. http://dx.doi.org/10.1046/j.1461-0248.1999.22057.x

[24] Wit, S.W. and Schwabe, A. (2010) The Fate of Sheep-Dispersed Seeds: Plant Species Emergence and Spatial Patterns. Flora, Morphology, Distribution, Functional Ecology of Plants, 205, 656-665. http://dx.doi.org/10.1016/j.flora.2010.04.010

[25] Harper, J.L. (1977) Population Biology of Plants. Academic Press, London.

[26] Legendre, P. and Fortin, M.J. (1989) Spatial Pattern and Ecological Analysis. Vegetatio, 80, 107-138. http://dx.doi.org/10.1007/BF00048036

[27] Condit, R., Ashton, P.S., Baker, P., Bunyavejchwin, S., Gunatilleke, S., Gunatilleke, N., Hubbell, S.P., Foster, R.B., Itoh, A., LaFrankie, J.V., Lee, H.S., Losos, E., Manokaran, N., Sukumar, R. and Yamakua, T. (2000) Spatial Patterns in the Distribution of Tropical Tree Species. Science, 288, 1414-1418. http://dx.doi.org/10.1126/science.288.5470.1414

[28] Okubo, A. and Levin, S.A. (1989) A Theoretical Framework for Data Analysis on Wind Dispersal of Seeds and Pollen. Ecology, 70, 329-338. http://biology.duke.edu/upe302/pdf\%20files/Gaby_okubo_levine.pdf http://dx.doi.org/10.2307/1937537

[29] Augspurger, C.K. and Franson, S.E. (1987) Wind Dispersal of Artificial Fruit Varying in Mass, Area, and Morphology. Ecology, 68, 27-42. http://www.jstor.org/stable/1938802 http://dx.doi.org/10.2307/1938802

[30] Crawley, M.J. (1997) Plant Ecology. Blackwell Scientific Publications, Oxford.

[31] Lortie, J. and Turkington, R. (2002) The Small-Scale Spatiotemporal Pattern of a Seed Bank in the Negev Desert, Israel. Écoscience, 9, 407-413.

http://www.ecoscience.ulaval.ca/en/paper/the-small-scale-spatiotemporal-pattern-of-a-seed-bank-in-the-negev-desert-is rael

[32] Horn, H.S., Nathan, R. and Kaplan, S.R. (2001) Long-Distance Dispersal of Tree Seeds by Wind. Ecological Research, 16, 877-885. http://dx.doi.org/10.1046/j.1440-1703.2001.00456.x 
Scientific Research Publishing (SCIRP) is one of the largest Open Access journal publishers. It is currently publishing more than 200 open access, online, peer-reviewed journals covering a wide range of academic disciplines. SCIRP serves the worldwide academic communities and contributes to the progress and application of science with its publication.

Other selected journals from SCIRP are listed as below. Submit your manuscript to us via either submit@scirp.org or Online Submission Portal.
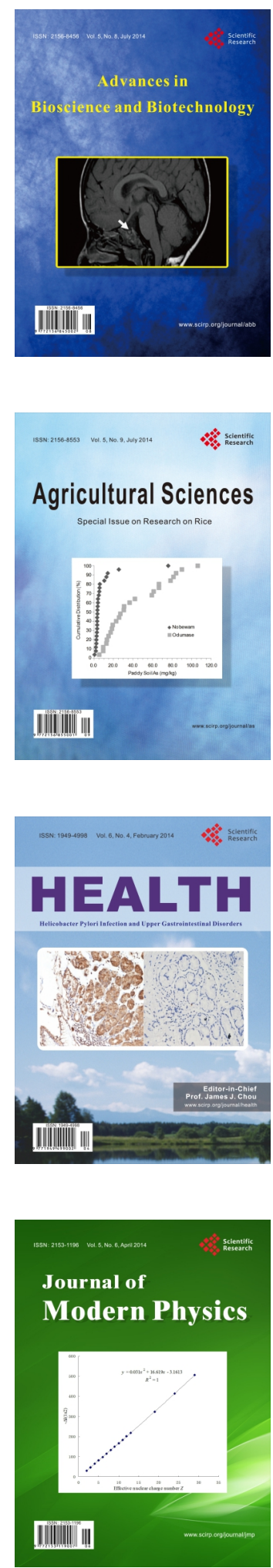
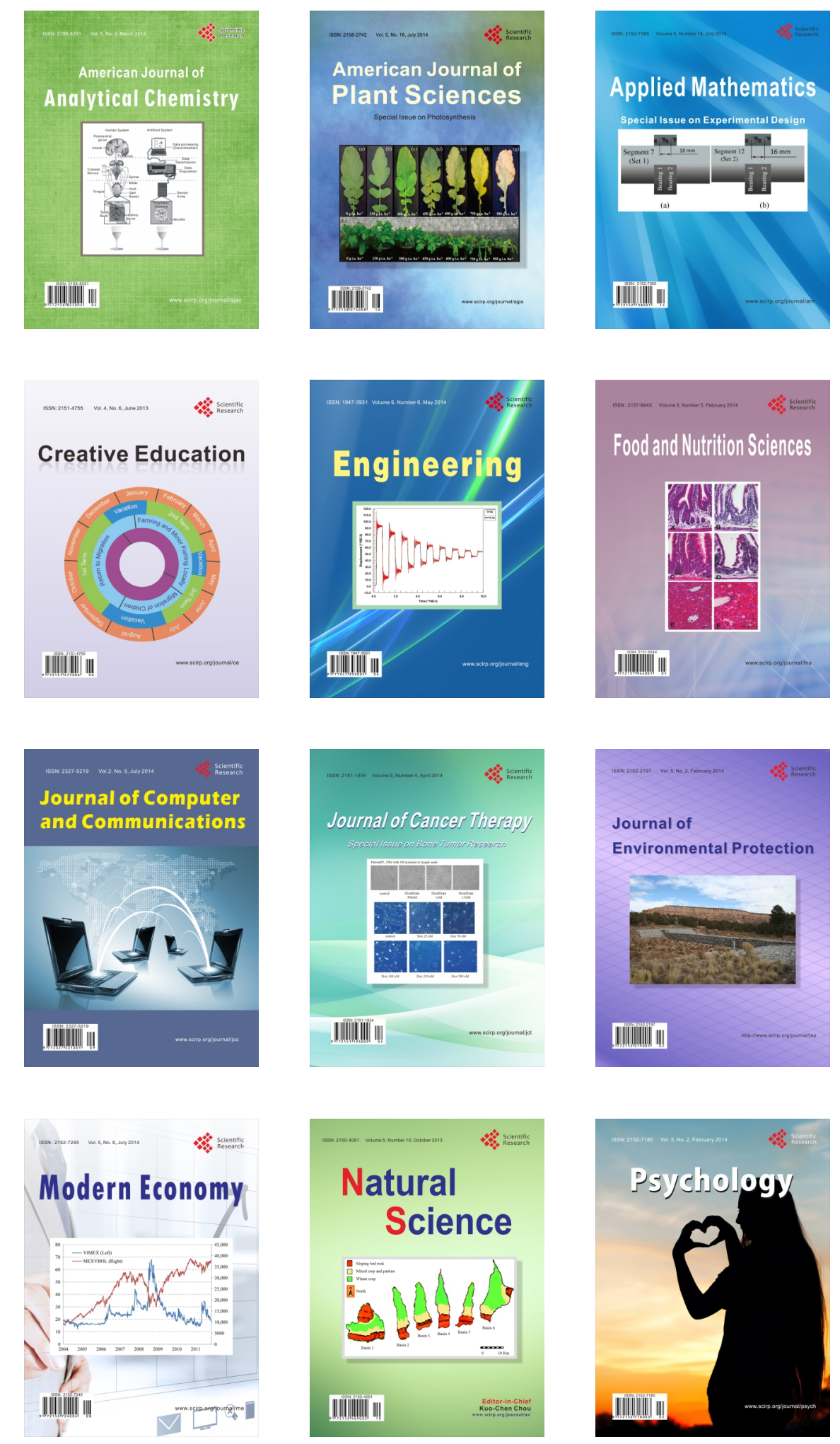